\title{
Expression of the Wilms' Tumor Gene WTI in Human Malignant Mesothelioma Cell Lines and Relationship to Platelet-Derived Growth Factor A and Insulin-Like Growth Factor 2 Expression
}

Anthonie W. Langerak, Kathleen A. Williamson, Kiyoshi Miyagawa, Anne Hagemeijer, Marjan A. Versnel, and Nicholas D. Hastie

Departments of Immunology (A.W.L., M.A.V.) and Cefl Biology and Genetics (A.H.). Erasmus University, Rotterdam, The Netherlands; MRC Human Genetics Unit, Western General Hospital, Edinburgh, United Kingdom (K.A.W., K.M., N.D.H.)

\begin{abstract}
Mutations in the WTI tumor suppressor gene are known to contribute to the development of Wilms' tumor (WT) and associated gonadal abnormalities. WTI is expressed principally in the fetal kidney, developing gonads, and spleen and also in the mesothelium, which lines the coelomic cavities. These tissues develop from mesenchymal components that have subsequently become epithelialized, and it has therefore been proposed that WTI may play a role in this transition of cell types. To test the possible involvement of this gene in malignant mesothelioma, we have first studied its expression in a panel of human normal and malignant mesothelial cell lines. WTI mRNA expression levels varied greatly between the cell lines and no specific chromosomal aberration on IIp, which could be related to the variation in WTI expression in these cell lines, was observed. Furthermore, no gross deletions, rearrangements, or functionally inactivating point mutations in the WTI coding region were identified. All four WTI splice variants were observed at similar levels in these cell lines. The WTI gene encodes a zinc-finger transcription factor and the four protein isoforms are each believed to act as transcriptional repressors of certain growth factor genes. Lack of WTI expression is thus predicted to result in growth stimulation of tumor cells. Binding of one particular WTI isoform construct to the insulin-like growth factor 2 (IGF2) and platelet-derived growth factor A (PDGFA) gene promoters has been demonstrated to result in repression of these genes in transient transfection studies. Analysis of IGF2 and PDGFA mRNA expression levels compared with WTI mRNA expression levels failed to demonstrate an inverse correlation in the mesothelial cell lines, which endogenously express these genes. Finally, the putative role of WTI in the transition of cell types was investigated. No obvious correlation between WTI expression levels and cell morphology of the malignant mesothelial cell lines was evident from this study. Moreover, no change in WTI expression was observed in normal mesothelial cells which were, by alteration of culture conditions, manipulated to switch from the mesenchymal to epithelial morphology. Genes Chromosom Cancer 12:87-96 (1995). (c) 1995 Wiley-Liss, Inc.
\end{abstract}

\section{INTRODUCTION}

Human malignant mesothelioma is a mesodermally derived tumor, which is most often found in the pleura. Its incidence is strongly associated with exposure to asbestos fibers (Wagner et al., 1960). Malignant mesothelioma is thought to develop from mesothelial cells, which form a specialized epithelium lining the coelomic cavities. Malignant mesothelioma was mentioned as one of the socalled second risk tumors in a few patients who had recovered from the pediatric kidney malignancy Wilms' tumor (WT) (Austin et al., 1986). This suggests the possible involvement of a common underlying genetic event in borh malignancies.

The WT1 locus on $11 \mathrm{p} 13$ has been identified as one of the chromosomal loci contributing to WT development (Call et al., 1990; Gessler et al., 1990). WT1 encodes a protein with DNA-binding capacity, elicited by four zinc-fingers at the C-terminal part, which bind to DNA sequences with the core consensus element 5'-GCGGGGGCG-3'
(Rauscher et al., 1990). The WT1 protein additionally possesses transcriptional regulatory activity exerted through the $\mathrm{N}$-terminal glutamine- and proline-rich regions of the protein (Madden et al., 1991). Alternative splicing of the WTl gene at two independent splice sites has been shown to result in the formation of four WT1 splice variants. In tumor tissue and fetal kidney there appears to be little variation in the ratios of these four isoforms (Haber et al., 1991; Brenner et al., 1992).

In transient transfection studies insulin-like growth factor 2 (IGF2), platelet-derived growth factor A (PDGFA), and IGFIR have recently been identified as potential target genes for transcriptional repression by WT1 (Drummond et al., 1992; Gashler et al., 1992; Wang et al., 1992; Werner et

Received May 30, 1994; accepted July 28, 1994.

Address reprint requests to Dr. Anthonie W. Langerak, Department of Immunology, Erasmus University, P.O. Box 1738, 3000 DR Rotterdam, The Netherlands. 
al., 1993). These and other results have led to the hypothesis that the WT1 protein functions as a tumor suppressor gene product and that reduction or absence of WT1 expression that is seen in a proportion of WTs results in an increased expression of certain growth factor genes. However, transactivation by WT1 was also seen, depending on the presence of wild-type TP53 protein, the number of WT1 binding sites in the promoter of the target gene, or the presence of specific missense mutations within the transregulatory domain (Maheswaran et al., 1993; Park et al., 1993a; Wang et al., 1993).

Despite these results on repression or activation of certain target genes by WT1 in transient assays, not much is known about the physiological role of WT1. It has been suggested that WT1 may play a role in mediating the shift from a mesenchymal to an epithelial phenotype, as it is expressed in the nephrogenic epithelia, in epithelial cells of the gonads, and in the mesothelium (Pritchard-Jones et al., 1990; Pelletier et al., 1991; Armstrong et al., 1992). These are all cells of mesodermal origin that have undergone the transition to the epithelial morphology. However, other cell types undergoing this transition do not express the WT1 gene, whereas in embryonic mice distinct regions in the spinal cord and brain that are of ectodermal origin display WT1 expression, arguing that there should be other tissue-specific roles for WT1 in development (Armstrong et al., 1992). Recently, a crucial role for $W T 1$ in early urogenital development was established in a model system by gene targeting in murine embryonic stem cells (Kreidberg et al., 1993). In these WT1 knockout mice a failure in kidney development was observed. This was suggested to be caused by inhibition of inductive events leading to the formation of the metanephric kidney. In addition, abnormal development of the gonads, the heart, and the mesothelium was seen as well. Abnormalities in the phenotypes of these tissues support the idea of a role for WT1 in the mesenchymal to epithelial cell transition.

As WT1 expression was observed in the human and mouse developing and mature mesothelium (Pritchard-Jones et al., 1990; Armstrong et al., 1992; Park et al., 1993b), we were interested to determine whether $W T 1$ was also expressed in its malignant counterpart as this might indicate a possible involvement of WT1 in the pathogenesis of malignant mesothelioma. In this respect, it is worth noting that cytogenetic analysis of 40 confirmed mesothelioma patients revealed karyotypic abnormalities in several chromosomes, but only in a few cases were rearrangements in $11 \mathrm{p}$ seen (Hagemeijer er al., 1990). We have studied expression of the WT1 gene in a panel of human normal and malignant mesothelial cell lines. Expression levels were related to the morphology (epithelial or mesenchymal) of the mesothelioma cells in vitro in order to clarify putative WT1 involvement in cell type transition. We also investigated whether gross alterations or point mutations could be detected at the WT1 locus, whether the four different alternatively spliced mRNAs were present in the various normal and malignant mesothelial cell lines, and whether the WT1 mRNA expression level in these cell lines could be correlated to their PDGFA and IGF2 mRNA levels.

\section{MATERIALS AND METHODS}

\section{Cell Lines, Growth Conditions, Characterization, and Cytogenetics}

Experiments were performed using the human pleural malignant mesothelioma cell lines Mero$14,-25,-41,-48 b,-48 c,-72,-82,-83,-84,-95,-96$, and -123 (Versnel et al., 1988, 1989) and the normal mesothelial cell lines NM-1, $-4,-5,-9$, and -12 (Versnel et al., 1991, 1993; Langerak et al., in preparation). All mesothelioma cell lines were derived from mesothelioma patients whose diagnosis was based on routine cytology, which was histologically or ultrastructurally confirmed. Cell lines were routinely cultured as described earlier (Versnel et al., 1988, 1989). Cytogenetic analysis was performed as described earlier (Versnel et al., 1988).

\section{Northern and Southern Blot Analyses and Probes}

Northern blotting and Southern blotting were performed as described in Langerak et al. (1992). For hybridization of Northern and Southern blots a $1.8 \mathrm{~kb} E c o \mathrm{RI} W T 1$ fragment derived from the W'T33 cDNA was used (Call et al., 1990). Northern blots were rehybridized with the $1.3 \mathrm{~kb} E c o \mathrm{RI}$ PDGFA fragment (Betsholtz et al., 1986), the 1.4 $\mathrm{kb} X b a \mathrm{I}-E c o \mathrm{RI} I G F 2$ fragment from pIGF-II (Jansen et al., 1985), and the $0.7 \mathrm{~kb} E c o$ RI- $P_{S t}$ I glyceraldehyde-3-phosphate dehydrogenase (GAPDH) fragment (Benham et al., 1984). Rehybridization of Southern blots was performed with a $1.3 \mathrm{~kb}$ Pst IGF2 fragment from pKT218 (Jansen et al., 1985).

\section{Reverse Transcription (RT) Polymerase Chain Reaction (PCR) Analysis}

RT of RNA, isolated from the normal and malignant mesothelial cell lines, and subsequent PCR 
analysis were performed as described previously (Langerak et al., 1992). For amplification of the alternative splice variants the sense primers B297 (5'-TTG GTC GAC ATG ACC TGG AAT CAG/C ATG-3'; located in WT1 exon 4) or B439 (5'-CTT GTA CGG TCG GCA TCT-3'; located in WT1 exon 7) were used in combination with antisense primer B298 (5'-TGC AAG CTT CAG CTG AAG GGT/C TTC/T TC-3'; located in WTI exon 10) (Little et al., 1992). Thirty-five cycles of $1 \mathrm{~min}$ at $94^{\circ} \mathrm{C}, 1 \mathrm{~min}$ at $50^{\circ} \mathrm{C}$, and $2 \mathrm{~min}$ at $72^{\circ} \mathrm{C}$ were performed. PCR products were analyzed on $10 \%$ polyacrylamide gels using Pstl digested lambda DNA as a marker.

\section{Point Mutation Analysis}

Chemical cleavage mismatch analysis using hydroxylamine and osmium tetroxide (HOT analysis) was performed as described (Cotton et al., 1988; Prosser et al., 1990). Templates were generated by RT-nested PCR (Hanson et al., 1993), a strategy required due to low yields of available RNA. The WT1 region encoding the transregulatory domain was amplified with outer primers D609 sense (5'CAA ACA GGA GCC GAG CTG G-3') and D610 antisense (5'-GCA CAT CCT GAA TGC CTC TG-3') followed by inner primers 1 and 3 (Brown et al., 1992). The DNA-binding domain was similarly amplified with primers C582 sense ( $5^{\prime}$-AAA TGG ACA GAA GGG CAG AGC-3') and C583 antisense (5'-T'TG GAA GTT GGA TGA AGA AGA TC-3') followed by primers 2 and 4 (Brown et al., 1992). PCR conditions for D609/D610 are step $1,1 \mathrm{~min}$ at $94^{\circ} \mathrm{C}$; step 2,30 cycles of $30 \mathrm{sec}$ at $94^{\circ} \mathrm{C}$, $1 \mathrm{~min}$ at $54^{\circ} \mathrm{C}$, and $1-2 \mathrm{~min}$ at $72^{\circ} \mathrm{C}$; step $3,10 \mathrm{~min}$ at $72^{\circ} \mathrm{C}$. Touchdown PCR conditions for C582/ C583 are step 1, 1 min at $94^{\circ} \mathrm{C}$; step 2, 30 cycles of $30 \mathrm{sec}$ at $92^{\circ} \mathrm{C}, 1 \mathrm{~min}$ at $62-57^{\circ} \mathrm{C}$ and $2 \mathrm{~min}$ at $72^{\circ} \mathrm{C}$; step $3,10 \mathrm{~min}$ at $72^{\circ} \mathrm{C}$. Samples generating cleaved fragments after HOT analysis were subjected to a second round of RT-nested PCR. Then the products were purified by $\beta$-Agarase I (New England Biolabs, Beverly, MA) and subsequently sequenced directly as described (Winship, 1989).

\section{RESULTS}

\section{WTI mRNA Expression in Mesothelial Cell Lines}

Expression of the WT1 gene was studied on Northern blots, containing total RNA from normal and malignant mesothelial cell lines of human origin. WT1 mRNA was found to be consistently expressed in the normal mesothelial cell lines, although some variation in the levels was observed
(Fig. 1). The WT1 expression level was highly variable in the investigated panel of malignant mesothelioma cell lines, ranging from very high (Mero-25) to nearly or totally undetectable (Mero$41,-72,-82,-83,-95$ ) (Fig. 1). WT1 mRNA expression levels were normalized over GAPDH mRNA levels after quantification by densitometric analysis (see Table 1).

Based on their histology, malignant mesotheliomas can be classified as epithelial, mesenchymal, or biphasic. The morphology of the cultured mesothelioma cells in monolayer can differ from the primary tumor-tissue morphology (see Table 1). In an attempt to clarify the possible role of the WTI gene product in the transition of certain cell types from a mesenchymal toward an epithelial morphology, WTI mRNA expression levels in the cultured mesothelioma cells were therefore related to the epithelial or fibrous/mesenchymal morphology of these cell lines. Although the highest WT1 mRNA level was observed in Mero-25, which has the clearest epithelial phenotype, WT/ expression was not completely confined to cell lines showing an epithelial or biphasic morphology. WT1 mRNA was undetectable in several cell lines with a fibrous morphology like Mero-41 and -72 , but other fibrous cell lines did express WT1 (Mero-83, -96, and -123). In cell lines that were predominantly either fibrous or epithelial, expression was observed occasionally (Mero-48b, $-48 \mathrm{c}$, and -84 ), and in others not at all (Mero-82 and -95).

The putative involvement of WT1 in the mesenchymal to epithelial shift was further studied using a second approach. It has been described that cultured normal mesothelial cells can adopt a mesenchymal (fibrous) or epithelial cell shape depending on the presence or absence of epidermal growth factor (EGF) in the culture medium, respectively (Connell and Rheinwald, 1983). Therefore, the WT1 mRNA level was determined in two normal mesothelial cell lines under these conditions. The two cell lines showed a more epithelial morphology upon removal of EGF [and hydrocortisone (HC)] for 3 days from the standard culture medium. However, analysis of RNA isolated from the mesothelial cells cultured for $72 \mathrm{hr}$ in the absence of EGF and $\mathrm{HC}$ did not result in a significantly altered level of WT1 mRNA (data not shown).

\section{Alternative Splicing Pattern of WTI}

The WT1 gene is capable of producing four different mRNAs by alternative splicing, which can lead to the insertion of an extra 51 bp (exon 5) upstream of the zinc-fingers and/or $9 \mathrm{bp}$ (giving rise 


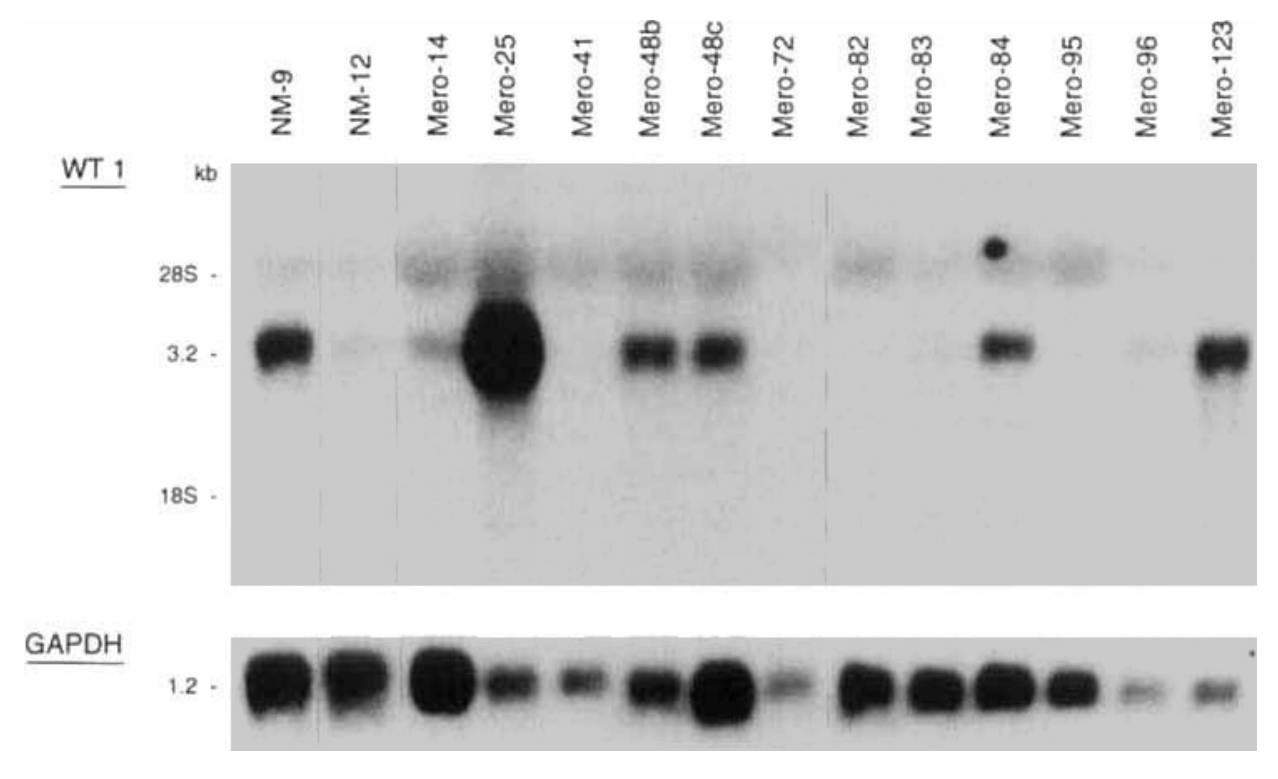

Figure I. Northern blot analysis with $25 \mu \mathrm{g}$ total RNA from normal (NM) and malignant (Mero) mesothelial cell lines. RNA was hybridized to WTI and GAPDH probes.

TABLE I. Summary of Cytogenetics, Tumor Cell Line Morphology, and WTI Expression in Normal (NM) and Malignant (Mero) Mesothelial Cell Lines

\begin{tabular}{|c|c|c|c|c|c|c|c|c|c|}
\hline \multirow[b]{2}{*}{ Cell line } & \multirow{2}{*}{$\begin{array}{c}\text { Tumor } \\
\text { cell line } \\
\text { morphology }\end{array}$} & \multirow{2}{*}{$\begin{array}{l}\text { Modal } \\
\text { chromo- } \\
\text { some } \\
\text { No. }\end{array}$} & \multicolumn{3}{|c|}{ No. of copies of chromosome (arm) } & \multirow{2}{*}{$\begin{array}{c}\text { WTI } \\
\text { mRNA } \\
\text { level }^{\mathrm{a}}\end{array}$} & \multirow{2}{*}{$\begin{array}{l}\text { WTI gene } \\
\text { structure } \\
\text { (Southern } \\
\text { blot) }\end{array}$} & \multirow{2}{*}{$\begin{array}{c}\text { WTI } \\
\text { gene } \\
\text { (mutations) }\end{array}$} & \multirow{2}{*}{$\begin{array}{c}\text { WTI } \\
\text { mRNA } \\
\text { (alternative } \\
\text { splicing) }\end{array}$} \\
\hline & & & $\begin{array}{l}\text { Normal } \\
\text { No. } 11\end{array}$ & $\begin{array}{l}\text { Rearranged } \\
\text { No. Ilp }\end{array}$ & $\begin{array}{l}\text { Total } \\
\text { No. IIP }\end{array}$ & & & & \\
\hline NM-I & - & 46 & 2 & - & 2 & 0.81 & ND & ND & 4 isoforms \\
\hline NM-4 & - & 46 & 2 & - & 2 & 0.28 & ND & ND & ND \\
\hline NM-5 & - & 46 & 2 & - & 2 & 0.12 & ND & ND & ND \\
\hline NM-9 & - & 46 & 2 & - & 2 & 0.26 & Normal & ND & ND \\
\hline NM-12 & - & 46 & 2 & - & 2 & 0.08 & ND & ND & ND \\
\hline Mero- 14 & Fibrous & 75 & $3(4)$ & - & $3(4)$ & 0.04 & Normal & Not found & 4 isoforms \\
\hline Mero-25 & Epithelial & 67 & $3(4)$ & $\mid \times \operatorname{inv}(\mid 1)(p|| q \mid 4)$ & $4(5)$ & 9.59 & Normal & Not found & 4 isoforms \\
\hline Mero-4I & Fibrous & 72 & 4 & - & 4 & 0 & Normal & ND & $N A^{c}$ \\
\hline Mero-48a & $\begin{array}{l}\text { Epithelial } \\
\text { (fibrous) }^{d}\end{array}$ & $71-75$ & 3 & $I \times \operatorname{mar}(t(9 p ;|| p))$ & 4 & ND & Normal & Not found & ND \\
\hline Mero-48b & $\begin{array}{l}\text { Fibrous } \\
\text { (epithelial) }\end{array}$ & $71-75$ & 3 & $1 \times \operatorname{mar}(t(9 p ; 11 p))$ & 4 & 0.43 & Normal & $\begin{array}{l}\text { Neutral } \\
\text { transition }\end{array}$ & ND \\
\hline Mero-48c & $\begin{array}{l}\text { Fibrous } \\
\text { (epithelial) }\end{array}$ & $7 I-75$ & 3 & $1 \times \operatorname{mar}(t(9 p ; \mid 1 p))$ & 4 & 0.12 & Normal & $\begin{array}{l}\text { Neutral } \\
\text { transition }\end{array}$ & 4 isoforms \\
\hline Mero-72 & Fibrous & 42 & 2 & - & 2 & 0 & Normal & ND & NA \\
\hline Mero-82 & $\begin{array}{l}\text { Fibrous } \\
\text { (epithelial) }\end{array}$ & 49 & 2 & - & 2 & 0 & Normal & ND & NA \\
\hline Mero-83 & Fibrous & $75-85$ & 2 & $2 \times$ add $I I p \mid 5$ & 4 & 0.04 & Normal & Not found & 4 isoforms \\
\hline Mero-84 & $\begin{array}{l}\text { Fibrous } \\
\text { (epithelial) }\end{array}$ & 38 & 0 & $\begin{array}{l}\mathrm{t}(6 \mathrm{p}+; 11 \mathrm{p}-) \\
+\operatorname{der}(11) \mathrm{t}(11 ; 22)\end{array}$ & 2 & 0.14 & Normal & Not found & 4 isoforms \\
\hline Mero-95 & Biphasic & $54-58$ & 3 & - & 3 & 0 & Normal & ND & NA \\
\hline Mero-96 & Fibrous & $72-78$ & $2(3)$ & $2 \times 6 q-(6 p:: 1 \mid p)$ & $4(5)$ & 0.26 & Normal & Not found & 4 isoforms \\
\hline Mero-123 & Fibrous & 55 & 3 & - & 3 & 0.91 & ND & $\begin{array}{l}\text { Neutral } \\
\text { transition }\end{array}$ & 4 isoforms \\
\hline
\end{tabular}

aShown over GAPDH expression levels as determined by densitometry.

$\mathrm{ND}$, not determined.

"NA, not applicable.

In parentheses: minority of the cells. 


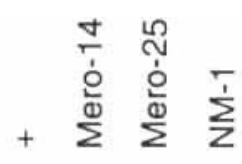

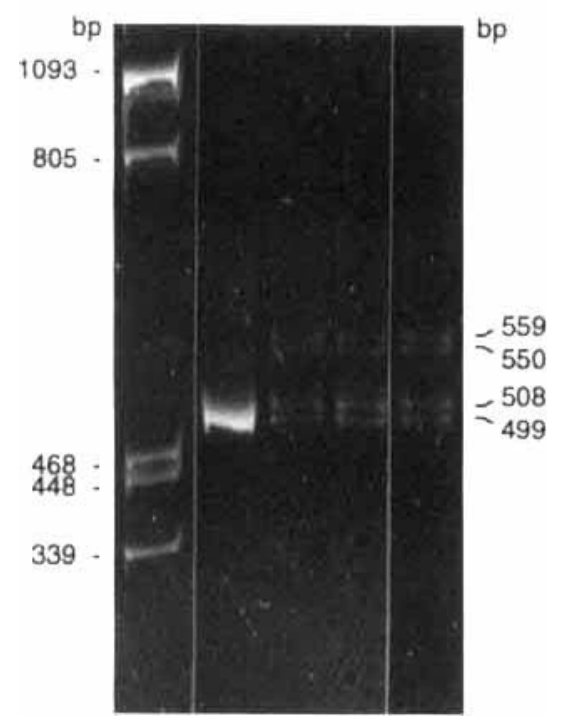

Figure 2. RT PCF analysis with RNA from malignant mesothelioma cell lines Mero- 14 and -25 and normal mesothelial cell line NM-I. WT33 cDNA was used as a positive control $(t)$. In the left lane Pstl digested lambda DNA was loaded as a size marker.

to the KTS amino acid sequence) between zincfingers 3 and 4 (Haber et al., 1991; Brenner et al., 1992). In this study the occurrence of these distinct WT1 mRNA forms was examined in clonal cell lines. For this purpose cDNA derived from total RNA of several of the WT1 expressing malignant mesothelioma cell lines (see Table 1) was used in a PCR reaction with primers B297 and B298. Four distinct DNA fragments of 499 bp $(-51 \mathrm{bp}$, -KTS), 508 bp (-51 bp, +KTS), 550 bp (+51 bp, -KTS), and $559 \mathrm{bp} \mathrm{(+51} \mathrm{bp,} \mathrm{+KTS),} \mathrm{result-}$ ing from two independent alternative splicing events, were observed (see Table 1). All four splice variants were detected in normal mesothelial cell line NM-1 as well. In Figure 2 these results are shown for the cell lines NM-1 and Mero-14 and -25. Using primers B439 and B298 in all cell lines studied, two distinct fragments of 320 and $329 \mathrm{bp}$ were seen, which result from the 9 bp alternative splicing event (data not shown). In our WTI mRNA expressing mesothelial cell lines, little variation was observed in the ratios of the four isoforms.

\section{Cytogenetic and Genomic Data Concerning WTI}

The variation in WT1 mRNA expression that we observed in the malignant mesothelioma cell lines could be due to differences in the whole or partial copy number of chromosome arm $11 \mathrm{p}$. Furthermore, rearrangements of the WTI gene or gene amplification may also be involved. To see if any of these possibilities may explain the variation in WTI mRNA level in the mesothelioma cell lines, cytogenetic analysis and Southern blotting were employed.

Cytogenetic data from the mesothelioma cell lines were obtained by studying metaphase cells. Analysis of chromosome arm 11p in the mesothelioma cell lines did not point toward any specific chromosomal aberration that could be correlated to their WT1 mRNA expression level (see Table 1). The aneuploidy of chromosome arm 11p and the WT1 mRNA level in the various cell lines did not correlate either (Table 1).

To see if gene rearrangements had occurred in those cell lines showing very low or undetectable amounts of WT1 mRNA, the WT1 gene was studied by Southern blot analysis. No differences were found in the EcoRI and HindIII digestion pattern of DNA from any of the malignant mesothelioma cell lines studied compared to the pattern of normal mesothelial cell line NM-9 (Fig. 3; also data not shown). This indicated that gross rearrangements in the WT1 gene had not occurred in the malignant mesothelial cell lines and thus were not likely to be the cause of undetectable WT1 mRNA expression in Mero-41, -72, -82, and $\mathbf{- 9 5}$.

By Southern blot analysis we did detect small differences in the intensity of the bands for the various cell lines, which could in principle be caused by variation in the number of WT1 gene copies. However, rehybridization of the filter containing HindIII digested DNA with a probe for the $I G F 2$ gene, which is also located on the short arm of chromosome 11 at $11 \mathrm{p} 15$, showed similar differences in intensity (data not shown). This meant that the WT1 gene was not differentially amplified in any of the cell lines. Variation in the number of copies of $11 \mathrm{p}$ may exist but in general the number of chromosome arm $11 \mathrm{p}$ largely balanced the total chromosome number, which suggests that the small differences in intensity are most probably due to small variations in loading of the gels.

\section{WTI Point Mutation Analysis}

The HOT technique of chemical cleavage mismatch analysis was used to scan virtually the entire coding sequence of $W T 1$ for point mutations. Only the first $256 \mathrm{bp}$ in exon 1 were omitted from this analysis, as the high GC content of this region renders it refractory to PCR amplification. The malig- 


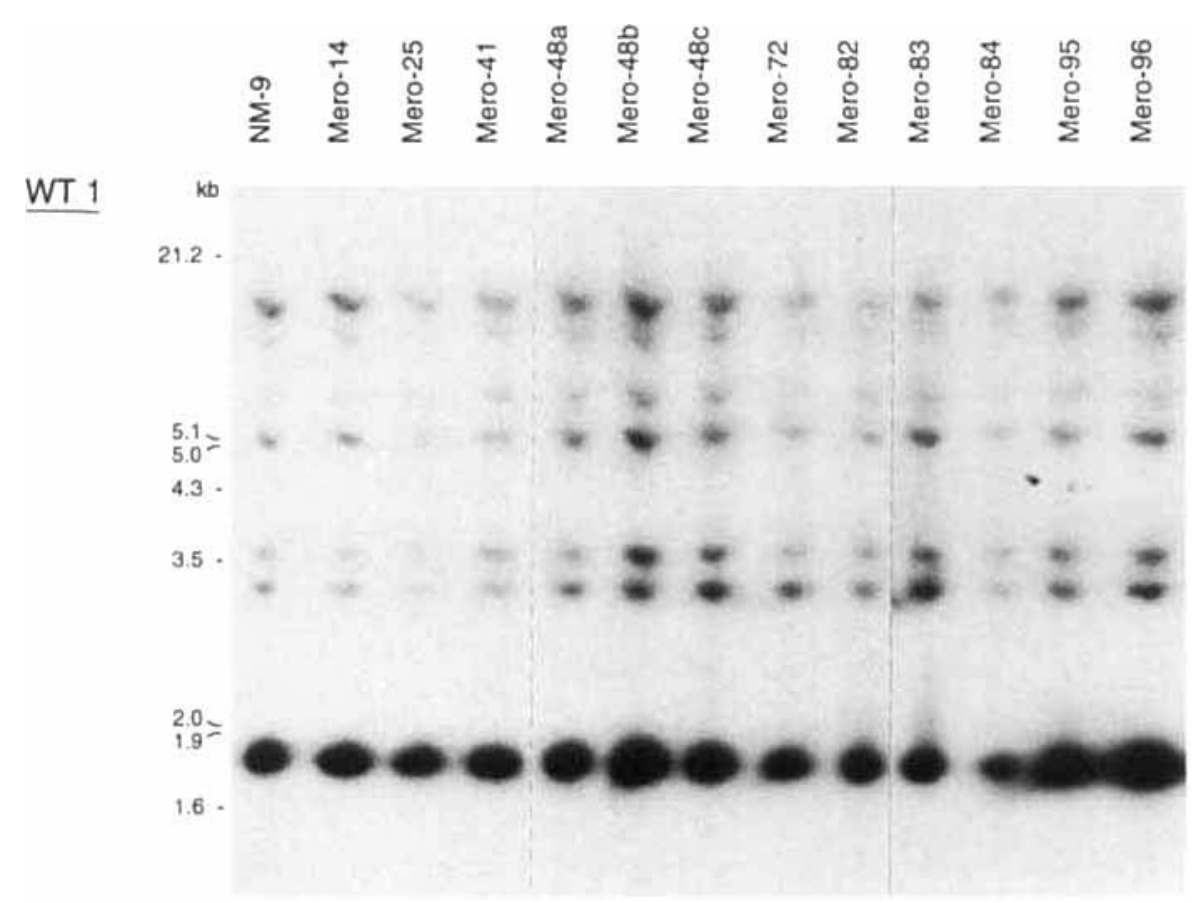

Figure 3. Southern blot analysis of the WTI gene. EcoRI-digested genomic DNA from a normal (NM-9) and several malignant (Mero) mesothelial cell lines was hybridized to a ${ }^{32}$ P-labeled WTI probe.

nant mesothelioma cell lines Mero-14, $-48 \mathrm{~b},-48 \mathrm{c}$, $-83,-84$, and -123 were scanned for point mutations in exons 1-6, encoding the transregulatory domain, and Mero-14, $-25,-48 b,-48 c,-83,-84,-96$, and -123 were scanned for point mutations in exons 6-10, encoding the DNA-binding domain. The only base change detected was a novel $\mathrm{C}$ to $\mathrm{T}$ transition at nucleotide 768 (numbered according to Gessler et al., 1990). This exon 1 transition is a third base change and does not cause amino acid substitution (AAC/T encodes an Asn residue). It is present in the homo/hemizygous state in Mero$48 \mathrm{~b},-48 \mathrm{c}$, and -123 (data not shown). No functionally inactivating nonsense or missense mutations were detected (see Table 1).

\section{WTI MRNA Expression in Relation to PDGFA and IGF2 mRNA Expression}

In transient transfection assays WT1 was reported to repress the expression of $P D G F A$ and $I G F 2$ promoter constructs. In order to see if the described variation in WT1 mRNA expression in our mesothelial cell lines could be related to different levels of PDGFA and IGF2 mRNA, blots were rehybridized with probes for these two genes and analyzed by densitometry. The results from a representative experiment are presented as arbitrary units over GAPDH signals in Table 2.
TABLE 2. mRNA Expression Levels of WTI, PDGFA, and IGF2 (6.0 and $4.8 \mathrm{~kb}$ ) in Normal (NM) and Malignant (Mero) Mesothelial Cell Lines, Expressed as Relative Densitometric Units Over GAPDH Expression Levels

\begin{tabular}{|c|c|c|c|c|}
\hline \multirow[b]{2}{*}{ Cell line ${ }^{a}$} & \multirow[b]{2}{*}{ WTI } & \multirow[b]{2}{*}{$P D G F A^{b}$} & \multicolumn{2}{|c|}{ IGF2 } \\
\hline & & & $6.0 \mathrm{~kb}$ & $4.8 \mathrm{~kb}$ \\
\hline NM-I & 0.81 & 0.65 & 0 & 0.53 \\
\hline NM-4 & 0.28 & 0.78 & 0.19 & 0.66 \\
\hline NM-9 & 0.26 & $N^{c}$ & 0 & 0.23 \\
\hline NM-5 & 0.12 & 0.62 & 0.12 & 0.48 \\
\hline NM-12 & 0.08 & ND & 0.23 & 0.48 \\
\hline Mero-25 & 9.59 & 1.42 & 0 & 0.73 \\
\hline Mero- 123 & 0.91 & 2.22 & 0 & 0.68 \\
\hline Mero-48b & 0.43 & 1.41 & 0.28 & 1.02 \\
\hline Mero-96 & 0.26 & 3.74 & 1.72 & 6.55 \\
\hline Mero-84 & 0.14 & 1.55 & 0.02 & 0.23 \\
\hline Mero-48c & 0.12 & 0.50 & 0.29 & 0.43 \\
\hline Mero-14 & 0.04 & 0.04 & 0 & 0.16 \\
\hline Mero-83 & 0.04 & 1.18 & 0.01 & 0.18 \\
\hline Mero-82 & 0 & 1.02 & 0 & 0.21 \\
\hline Mero-72 & 0 & 2.59 & 2.37 & 2.62 \\
\hline Mero-95 & 0 & 2.62 & 0.07 & 0.44 \\
\hline Mero-41 & 0 & 7.54 & 0.24 & 1.27 \\
\hline
\end{tabular}

${ }^{a}$ Cell lines are arranged in descending order of WTI expression levels.

'Totaled leveis of $2.8,2.3$, and 1.9 kb PDGFA transcripts. 'ND, not determined. 


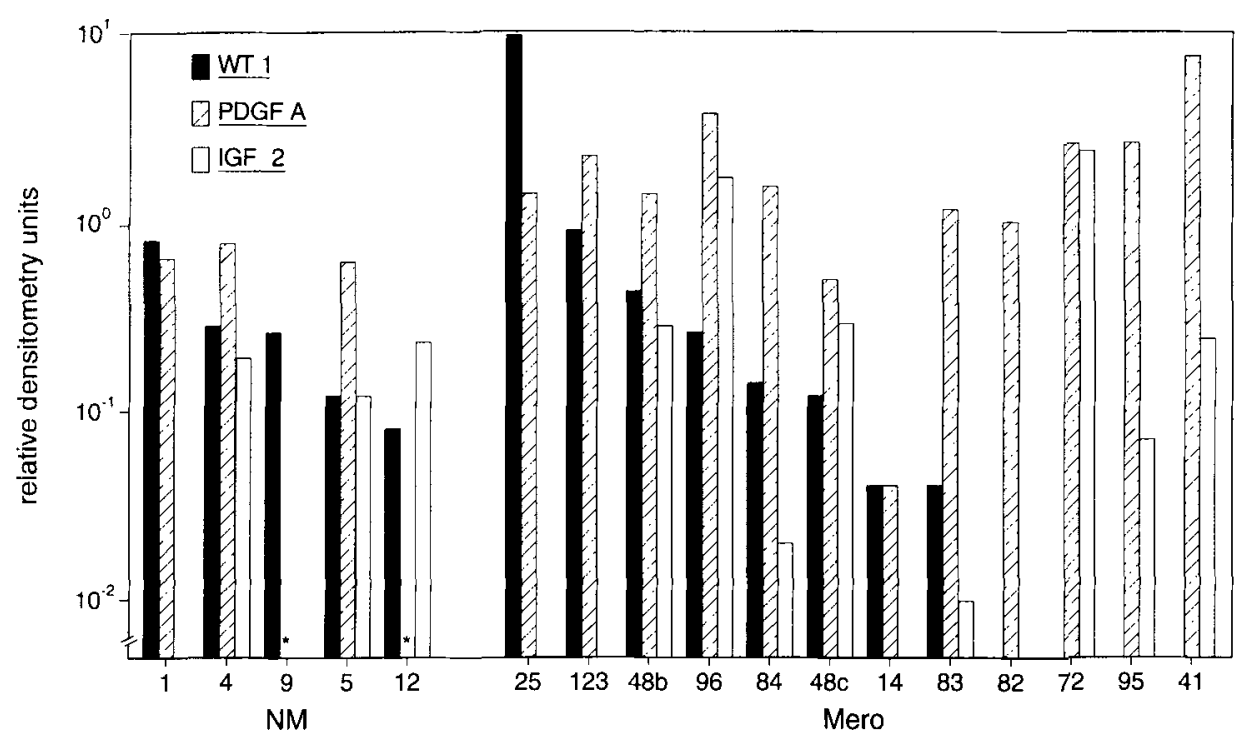

Figure 4. Relative densitometric units of the mRNA expression levels of WTI, PDGFA $(2.8,2.3$, and $1.9 \mathrm{~kb}$ totaled) and IGF2 $(6.0 \mathrm{~kb})$ in normal (NM) and malignant (Mero) mesothelial cell lines. The data are

The densitometric data of the three PDGFA transcripts $(2.8,2.3$, and $1.9 \mathrm{~kb})$ were totaled, as expression of these three messengers is under control of a single promoter region that contains consensus WT1 binding sequences. Our mesothelioma cell lines demonstrated variation in PDGFA mRNA expression, but in general the expression level was higher than in normal mesothelial cell lines. In a few cell lines lacking WT1 mRNA, a relatively high PDGFA expression was seen (Mero41, -72, and -95), but other cell lines which did show WT1 mRNA expression, i.e., Mero-96 and -123, displayed a similar $P D G F A$ mRNA level. Cell line Mero-25, in which a very high WTI mRNA level was seen, showed an intermediate level of PDGFA expression. This intermediate PDGFA level, however, was also seen in cell lines with a lower WT1 mRNA content than Mero-25. So, as is also illustrated in Figure 4, no clear correlation was observed between $W T 1$ and PDGFA expression in our mesothelial cell lines.

The $6.0 \mathrm{~kb} \mathrm{lGF2}$ transcript is the product of the fetal P3 promorer, which contains WT1 consensus binding sequerices, whereas the $4.8 \mathrm{~kb}$ transcript is expressed from a different fetal promoter (P4), also containing consensus WT1 binding sequences. Relatively high WT1 mRNA levels were found in cell lines which do not express the $6.0 \mathrm{~kb} I G F 2$ transcript (NM-1 and Mero-25 and -123), but other cell lines which demonstrated very low or no $6.0 \mathrm{~kb}$ IGF 2 mRNA expression, like NM-9 and Mero-14, $-82,-83,-84$, and -95 , showed a low or intermedi- presented on a log scale. See Table 2 for the exact densitometric units. Cell lines are arranged in descending order of WTI expression levels. Expression levels that were not determined are indicated by an asterisk.

ate WT1 mRNA level. In the panel of normal and mesothelial cell lines no clear relationship, reciprocal or otherwise, was observed between the 6.0 kb IGF 2 and WT1 mRNA level (see also Fig. 4). The same holds true for the expression level of the $4.8 \mathrm{~kb} I G F 2$ transcript.

\section{DISCUSSION}

The WT gene WT1 on 11p13 acquired its name, as it was originally mapped by deletion analysis of individuals with the WAGR (WT, aniridia, genitourinary abnormalities, and mental retardation) syndrome (Riccardi et al., 1978; van Heyningen et al., 1985). The demonstration of constitutional and somatic intragenic deletions in the WTI gene in a proportion of WT patients has confirmed that it is a WT predisposition gene (Haber et al., 1990; Cowell et al., 1991; Huff et al., 1991; Brown et al., 1992; Tadokoro et al., 1992). In expression studies in human and mouse embryos the WT1 gene was reported to be involved in normal genitourinary development (Pritchard-Jones et al., 1990; Armstrong et al., 1992). Because of this limited spatial expression, $W T 1$ was suggested to be important in tissues which are of mesodermal origin and which undergo a mesenchymal to epithelial transition, although expression was also observed in the spinal cord and developing brain. In situ hybridization studies showed high WT1 expression in the developing Sertoli cells of the testis and granulosa cells of the ovary (Pelletier et al., 1991; Armstrong et al., 1992). 
As the studies by Pritchard-Jones et al. (1990) and Armstrong et al. (1992) had revealed the expression of WT1 in the mesothelium, a specialized epithelium lining the coelomic cavities, an obvious question was if expression of the WT1 gene could be detected in mesothelioma as well. This prompted us to study WTl expression in a panel of normal and malignant human mesothelial cell lines. Northern blot analysis revealed the consistent presence of WT1 mRNA in cultured normal mesothelial cells, whereas in cultured malignant mesothelioma cells a variation in the expression level, ranging from very high to undetectable, was seen. We also found that the apparent lack of WT1 mRNA expression in several of these cell lines probably was not due to deletions or rearrangements in the WT1 gene. Furthermore, differences in the WT1 mRNA expression level between different cell lines could not be accounted for by gene amplification or a specific chromosomal aberration on $11 \mathrm{p}$. Differences in transcription initiation or RNA degradation thus most probably account for the variation in WT1 mRNA expression between the malignant mesothelioma cell lines.

When the WT1-expressing malignant mesothelioma cell lines were analyzed for more subtle alterations within the coding sequence, no nonsense or missense mutations were found. Three lines contained an identical $\mathrm{C}$ to $\mathrm{T}$ transition in the sequence encoding the transregulatory domain. However, this mutation is predicted to be silent at the protein level and therefore most likely pathologically insignificant. Recently a homozygous WT1 missense mutation that alters a Ser residue in the transregulatory domain has been reported for a single case of human peritoneal mesothelioma (Park et al., 1993b). This case is unusual in that the mesothelioma was not asbestos-related and was not actually a malignant tumor but rather a developmental abnormality. In addition, Park et al. (1993b) found no WT1 mutations in 32 specimens of asbestos-related mesothelioma. For our samples it is possible that there are undetected WT1 mutations in the $5^{\prime}$-most coding region of exon 1 or in the untranslated or intronic sequences of the gene. The cell lines that fail to show WT1 mRNA expression may additionally have mutations in the promoter/control regions of the gene. Differences in the occurrence of the four alternative splicing products, which may result in altered specificity for DNA binding sites (Bickmore et al., 1992), were not observed in our panel of WT1 expressing mesothelial cell lines. All four variants were identified earlier in WT tissue and in fetal kidney (Haber et al., 1991; Brenner et al., 1992). In these tissues the transcripts with the 9 bp alternative splice were suggested to be slightly predominant, whereas in our mesothelial cell lines we did not observe this, but a more quantitative assay has to be performed to unravel this putative discrepancy.

Taken together, the results obtained in our panel of malignant mesothelioma cell lines thus suggest that the WT1 gene may play a role as a tumor suppressor gene in a minority of human mesotheliomas. To test this in vivo, we started to study primary tumor material from mesothelioma patients. WT1 mRNA expression could be observed in cells from pleural effusions of four malignant mesothelioma patients (data not shown). These pleural fluids, however, contain tumor cells in combination with several other cell types, which means that this expression cannot be simply attributed to tumor cells, even though pleural fluids with a high percentage of mesothelioma cells were analyzed. Immunofluorescence staining with W'T1 antibodies and/or RNA in situ hybridization would be more informative in this respect.

As the ovarian surface epithelium is considered to be a specialized mesothelium (Papadaki and Beilby, 1971) and several ovarian carcinoma cell lines demonstrated a comparable $P D G F A$ and $P D G F B$ mRNA expression to malignant mesothelioma cell lines (Versnel et al., 1994), we also analyzed several ovarian carcinoma cell lines for WT1 mRNA expression. Comparable to the expression in malignant mesothelioma cell lines, in three of six serous ovarian carcinoma cell lines studied, WT1 expression was observed on Northern blots, while in the other three no WT1 transcripts were detected (data not shown). Furthermore, we recently observed a very high WT1 mRNA level in cell line COV-434, which is derived from a granulosa tumor of the ovary and thus is not of mesothelial origin (data not shown). This expression is in agreement with the observed WT1 expression in ovarian granulosa cells (Armstrong et al., 1992).

Malignant mesotheliomas are classified as epithelial, fibrous/mesenchymal, or biphasic. We therefore tried to correlate the morphology of the various malignant mesothelioma cell lines with their WT1 mRNA expression level. Although the highest expression was found in cell line Mero-25, which has the most obvious epithelial morphology, no clear correlation could be observed between WT1 mRNA expression and morphology. Moreover, normal mesothelial cells which can switch in morphology depending on the addition or removal of $\mathrm{EGF}$ from the culture medium, showed similar 
WT1 expression levels independent of the phenotype of the cells. So in these mesothelial cell lines no evidence could be found for a WT1 role in the mesenchymal to epithelial transition of cells. However, this may be different in vivo. Therefore, mesothelioma tissue from patients with a biphasic (i.e., with mesenchymal and epithelial elements) malignant mesothelioma should be studied with WT1 antibodies or by RNA in situ hybridization to investigate the putative correlation between WTI expression and morphology in vivo.

It has been shown in transient transfection assays that WT1 represses PDGFA (Gashler et al., 1992; Wang et al., 1992) and $I G F 2$ mRNA expression (Drummond et al., 1992). Our panel of normal and malignant mesorhelial cell lines showing variation in WT1 mRNA expression was analyzed for PDGFA and $I G F 2 \mathrm{mRNA}$ levels as well. No clear relationship, reciprocal or otherwise, between WT1 and $P D G F A$ or IGF? expression was found in our cell lines. The fact that no clear correlation could be found in cells endogenously expressing these genes is in contrast with the repression seen in the forementioned studies. However, these data were obtained in cells upon transfection of WT1 expression constructs together with $P D G F A$ and $I G F 2$ reporter constructs, whereas we looked at endogenous expression levels in a panel of cell lines. It may also be that in our mesothelial cell lines other factors are also involved in regulating $P D G F A$ and IGF2 mRNA expression, thereby masking regulation by WT1. Alternatively, mutations in the WT1 binding sequences in the promoters of these genes may prohibit WT1 regulation. It remains to be determined, whether WT1 can regulate expression of these genes in a physiological context. Evidence for this may come from stable transfection of the WT1 gene in Mero cell lines lacking WT1 or knocking out the endogenous WT1 gene expression in WT1 expressing cell lines.

In summary, we have shown that WT1 mRNA is consistently expressed in normal mesothelial cell lines and that there is no expression in a minority of malignant mesothelioma cell lines. No indications were found for chromosomal aberrations, deletions, rearrangements, functionally inactivating missense or nonsense mutations, or an aberrant alternative splicing pattern in these cell lines. The WT1 expression level does not seem to correlate with the mesenchymal or epithelial morphology of the various cell lines in vitro. No inverse correlation between WTI and PDGFA or IGF2 mRNA expression was seen in our panel of mesothelial cell lines, which endogenously express these genes.

\section{ACKNOWLEDGMENTS}

We thank Prof. Dr. R. Benner for continuous support and Mrs. E. Postma for technical assistance. Dr. M. Jansen kindly provided the $I G F 2$ probe. Mr. T.M. van Os is acknowledged for photographic assistance and Mrs. A.C. de Vries for secretarial assistance. This study was financially supported by a grant from the Dutch Cancer Society.

\section{REFERENCES}

Armstrong JF, Pritchard-Jones K, Bickmore WA, Hastie ND, Bard JBL (1992) The expression of the Wilms' tumour gene. WT1, in the developing mammalian embryo. Mech Dev 40:85-97.

Austin MB, Fechner RE, Roggli VL (1986) Pleural malignant mesothelioma following Wilms' tumor. Am J Clin Pathol 86:227. 230 .

Benham FJ, Hodgkinson S, Davies KE (1984) A glyceraldehvde-3phosphate dehydrogenase pseudogene on the short arm of the human X-chromosome defines a multigene family. EMBO J 3:2635-2640.

Betsholtz C, Johnsson A, Heldin C-H, Westermark B, Lind P, Urdea MS, Eddy R, Shows TB, Philpott K, Mellor AL, Knott TJ, Scott J (1986) cDNA sequence and chromosomal localization of human platelet-derived growth factor A-chain and its expression in tumor cell lines. Nature 320:695-699.

Bickmore WA, Oghene K, Little MH, Seawright A, van Heyningen V, Hastie ND (1992) Modulation of DNA binding specificity by alternative splicing of the Wilms' tumour wtl gene transcript. Science 257:235-237.

Brenner B, Wildhardt G, Schneider S, Royer-Pokora B (1992) RNA polymerase chain reaction detects different levels of four alternatively spliced WT1 transcripts in Wilms' tumors. Oncogene 7:1431-1433.

Brown KW, Watson JE, Poirier V, Mott MG, Berry PJ, Maitland NJ (1992) Inactivation of the remaining allele of the WT1 gene in a Wilms' tumour from a WAGR patient. Oncogene 7:763-768.

Call KM, Glaser T, Ito CY, Buckler AJ, Pelletier J, Haber DA, Rose EA, Kral A, Yeger H, Lewis W, Jones C, Housman DE (1990) Isolation and characterization of a zinc-finger polypeptide gene at the human chromosome Wilms' tumor locus. Cell 60:509-520.

Connell ND, Rheinwald JG (1983) Regulation of the cytoskeleton in mesothelial cells: Reversible loss of keratin and increase in vimentin during rapid growth in culture. Cell 34:245-253.

Cotton RG, Rodrigues NR, Campbell RD (1988) Reactivity of cytosine and thymine in single-base-pair mismatches with hydroxylamine and osmium tetroxide and its application to the study of mutations. Proc Nat Acad Sci USA 85:4397-4401.

Cowell JK, Wadey RB, Haber DA, Call KM, Housman DE, Pritchard J (1991) Structural rearrangements of the $W T 1$ gene in Wilms tumour cells. Oncogene 6:595-599.

Drummond IA, Madden SL, Rohwer-Nutter P, Bell GI, Sukhatme VP, Rauscher FJ III (1992) Repression of the insulin-like growth factor II gene by the Wilms' tumor suppressor WT1. Science 257:674-678.

Gashler AL, Bonthron DT, Madden SL, Rauscher FJ III, Collins $T$, Sukhatme VP (1992) Human platelet-derived growth factor A-chain is transcriptionally repressed by the Wilms' tumor suppressor WT1. Proc Natl Acad Sci USA 89:10984-10988

Gessler M, Poustka A, Cavenee W, Neve RL, Orkin SH, Bruns GAP (1990) Homozygous deletion in Wilms' tumours of a zincfinger gene identified by chromosome jumping. Nature $343: 774-$ 778 .

Haber DA, Buckler AJ, Glaser T, Call KM, Pelletier J, Sohn RL, Douglass EC, Housman DE (1990) An internal deletion within an 11 p 13 zinc-finger gene contributes to the development of Wilms' tumor. Cell 61:1257-1269.

Haber DA. Sohn RL, Buckler AJ, Pelletier J, Call KM, Housman DE (1991) Alternative splicing and genomic structure of the Wilms tumor gene WT1. Proc Natl Acad Sci USA 88:9618-9622.

Hagemeijer A, Versnel MA, van Drunen E, Moret M, Bouts MJ, van der Kwast ThH, Hoogsteden HC (1990) Cytogenetic analysis of malignant mesothelioma. Cancer Genet Cytogenet 47:1-28.

Hanson IM, Seawright A, Hardman K, Hodgson S, Zaletayev D, 
Fekete G, van Heyningen $\mathrm{V}$ (1993) PAX6 mutations in aniridia. Hum Mol Genet 2:915-920.

Huff V, Miwa H, Haber DA, Call KM, Housman DE, Strong L, Saunders GF (1991) Evidence for WTI as a Wilms' tumor (WT) gene: Intragenic germinal delerion in bilateral WT. Am J Hum Genet 48:997-1003.

Jansen M, van Schaik FMA, van Tol H, van den Brande JL, Sussenbach JS (1985) Nucleotide sequences of CDNAs encoding precursors of human insulin-like growth factor-II (IGF-II) and an IGF-II variant. FEBS Lett 179:243-246.

Kreidberg JA, Sariola H, Loring JM, Maeda M, Pelletier J, Housman D, Jaenisch R (1993) WT-1 is required for early kidney development. Cell 74:679-691.

Langerak AW, Dirks RPH, Versnel MA (1992) Splicing of the platelet-derived growth factor A-chain mRNA in human malignant mesothelioma cell lines and regulation of its expression. Eur J Biochem 208:589-596.

Little MH, Prosser J, Condie A, Smith PJ, van Heyningen V, Hastic ND (1992) Zinc finger point mutations within the $W T]$ gene in Wilms' tumor patients. Proc Natl Acad Sci USA 89:4791-4795.

Madden SL, Cook DM, Morris JF, Gashler A, Sukhatme VP, Rauscher FJ III (1991) Transcriptional repression mediated by the WT1 Wilms' tumor gene product. Science 253:1550-1553.

Maheswaran S, Park S, Bernard A, Morris JF, Rauscher FJ III, Hill DE, Haber DA (1993) Physical and functional interactions between WT1 and p53 proteins. Proc Natl Acad Sci USA 90:51005104.

Papadaki L, Beilby JOW (1971) The fine structure of the surface epithelium of the human ovary. J Cell Sci 8:445-465.

Park S, Tomlinson G, Nisen P, Haber DA (1993a) Altered transactivational properties of a mutated WTI gene product in a WAGRassociated Wilms' tumor. Cancer Res 53:4757-4760.

Park S, Schalling M, Bernard A, Maheswaran S, Shipley GC, Roberts D, Fletcher J. Shipman R, Rheinwald J. Demetri G. Griffin J. Minden M, Housman DE, Haber DA (1993b) The Wilms' tumor gene $W T 1$ is expressed in murine mesoderm-derived tissues and mutated in a human mesorhelioma. Nat Genet 4:415420.

Pelletier J, Schalling M, Buckler AJ, Rogers A, Haber DA, Housman DE (1991) Expression of the Wilms' tumour gene WT1 in the murine urogenital system. Genes Dev 5:1345-1356.

Pritchard-Jones K. Fleming S, Davidson D, Bickmore W, Porteous D, Gosden C, Bard J, Buckler A, Pelletier J, Housman D, van Heyningen V, Hastie ND (1990) The candidate Wilms' tumour gene is involved in genitourinary development. Nature 346:194197.

Prosser J, Thompson AM. Cranston G, Evans HJ (1990) Evidence that $\mathrm{p} 53$ behaves as a tumour suppressor gene in sporadic breast tumours. Oncogene 5: 1573-1579.

Rauscher FJ III, Morris JF, Tournay OE, Cook DM, Curran T (1990) Binding of the Wilms' tumor locus zinc-finger protein to the EGR-1 consensus sequence. Science 250:1259-1262.

Riccardi VM, Sujanski E, Smith AC, Francke U (1978) Chromo- somal imbalance in the aniridia-Wilms' tumor association: $11 \mathrm{p}$ interstitial deletion. Pediatrics 61:604-610.

Tadokoro K, Fujii H, Ohshima A, Kakizawa Y, Shimizu K, Sakai A, Sumiyoshi K, Inoue T, Hayashi Y, Yamada M (1992) Intragenic homozygous deletion of the WTI gene in Wilms' tumor. Oncogene 7:1215-1221.

van Heyningen V, Boyd PA, Seawright A, Fletcher JM, Fantes JA, Buckton KE, Spowart G, Porteous DJ, Hill RE, Newton MS, Hastie ND (1985) Molecular analysis of chromosome 11 deletions in aniridia-Wilms' tumour syndrome. Proc Natl Acad Sci USA 82:8592-8596.

Versnel MA, Hagemeijer A, Bouts MJ, van der Kwast ThH, Hoogsteden HC (1988) Expression of c-sis (PDGF B-chain) and PDGF A-chain genes in ten human malignant mesothelioma cell lines derived from primary and metastatic tumours. Oncogene 2:601-605.

Versnel MA. Bouts MJ, Hoogsteden HC, van der Kwast ThH, Delahaye M, Hagemeijer A (1989) Establishment of human malignant mesothelioma cell lines. Int J Cancer 44:256-260.

Versnel MA, Claesson-Welsh L, Hammacher A, Bouts MJ, van der K'wast ThH. Eriksson A, Willemsen R, Weima SM, Hoogsteden HC, Hagemeijer A, Heldin C-H (1991) Human malignant mesothelioma cell lines express PDGF $\beta$-receprors, whereas cultured normal mesothelial cells express predominantly PDGF $\alpha$-receptors. Oncogene 6:2005-2011.

Versnel MA, Langerak AW, van der Kwast ThH, Hoogsteden HC, Hagemeijer A (1993) Expression of PDGF chains and PDGF receptors in normal and malignant mesothelial cell lines. Eur Respir Rev 3:186-188.

Versnel MA, Haarbrink M, Langerak AW, de Laat PAJM, Hagemeijer A, van den Berg L, Schrier PI (1994) Human ovarian tumours from epithelial origin express PDGF in vitro and in vivo. Cancer Genet Cytogenet 73:60-64.

Wagner JC, Sleggs CA, Marchand P (1960) Diffuse pleural mesothelioma and asbestos exposure in the North-Western Cape Province. Br J Ind Med 17:260-270.

Wang ZY, Madden SL, Deuel TF, Rauscher FJ III (1992) The Wilms' tumor gene product WTI represses transcription of the platelet-derived growth factor A-chain gene. J Biol Chem 267: 21999-22002.

Wang ZY, Qiu QQ, Deuel TF (1993) The Wilms' tumor gene produce $W T 1$ activates or suppresses transcription through separate funcrional domains. J Biol Chem 268:9172-9175.

Werner H, Re GG, Drummond IA, Sukharme VP. Rauscher FJ III, Sens DA, Garvin AJ, LeRoith D, Roberts C (1993) Increased expression of the insulin-like growth factor 1 receptor gene, $I G F I R$, in Wilms' tumor is correlated with modulation of $I G F I R$ promoter activity by the WTI Wilms' tumor gene product. Proc Natl Acad Sci USA 90:5828-5832.

Winship PR (1989) An improved method for directly sequencing PCR amplified material using dimethyl sulphoxide. Nucleic Acids Res 17:1266. 